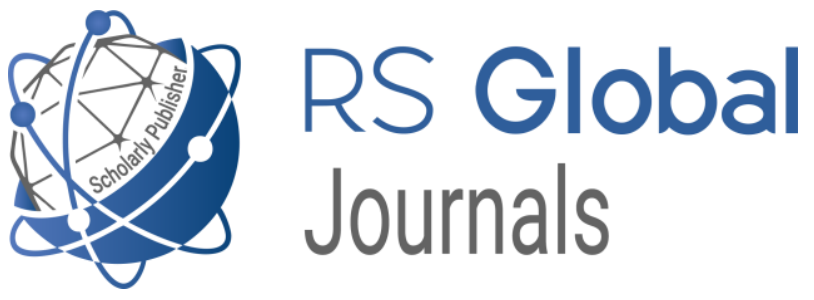

Scholarly Publisher

RS Global Sp. z O.O.

ISNI: 0000000484952390

Dolna 17, Warsaw, Poland 00-773

Tel: +48226022703

Email: editorial_office@rsglobal.pl

JOURNAL International Journal of Innovative Technologies in Social Science

p-ISSN

$2544-9338$

e-ISSN

2544-9435

PUBLISHER

RS Global Sp. z O.O., Poland

ARTICLE TITLE

ПІДГОТОВКА МАЙБУТНІХ УЧИТЕЛІВ МУЗИЧНОГО МИСТЕЦТВА ДО ІНСТРУМЕНТАЛЬНОГО ВИКОНАВСТВА

AUTHOR(S) Щербак Ігор Вікторович

Shcherbak I. V. (2020) Preparation of Future Teachers of Music

ARTICLE INFO Art for Instrumental Performance. International Journal of Innovative Technologies in Social Science. 7(28). doi: 10.31435/rsglobal_ijitss/30122020/7234

DOI https://doi.org/10.31435/rsglobal_ijitss/30122020/7234

RECEIVED

19 September 2020

ACCEPTED

14 November 2020

PUBLISHED

19 November 2020

LICENSE

This work is licensed under a Creative Commons Attribution

4.0 International License.

(C) The author(s) 2020. This publication is an open access article. 


\title{
ПІДГОТОВКА МАЙБУТНІХ УЧИТЕЛІВ МУЗИЧНОГО МИСТЕЦТВА ДО ІНСТРУМЕНТАЛЬНОГО ВИКОНАВСТВА
}

\author{
Щербак Ігор Вікторович, \\ кандидат педагогічних наук, доцент кафедри музичного мистеитва \\ МНУ ім. В.О. Сухомлинського, м. Миколаїв, Украӥна, \\ ORCID ID: https://orcid.org/0000-0002-4649-6510
}

DOI: https://doi.org/10.31435/rsglobal_ijitss/30122020/7234

\section{ARTICLE INFO}

Received 19 September 2020 Accepted 14 November 2020 Published 19 November 2020

\section{KEYWORDS}

instrumental performance training, prospective teacher, music art, musical instrument, music, musician, artistic image.

\begin{abstract}
The article reviews the concept of instrumental performance training for prospective music teacher through the prism of system approach. It is considered to be psychological and educational issue in terms of the tasks for instrumental performance practice of specialists in comprehensive school. The author points out that the implementation of all kinds of instrumental performance practice of prospective music teacher should be found on the fusion of instrumental performance, psychological and pedagogical skills, sophisticated aesthetic taste and conscious respect to music. The author of the article believes that the intention to equip students with profound book learning and methodological knowledge in the domain of instrumental performance practice should be pursued through the development of their intellectual abilities, formation of genre and stylistic notion, faculty to make sense of musical forms and art expressive means. Improving the quality of professional training of future music teachers, in particular the improvement of their instrumental and performing skills is one of the leading tasks of modern music and pedagogical education.
\end{abstract}

Citation: Shcherbak I. V. (2020) Preparation of Future Teachers of Music Art for Instrumental Performance. International Journal of Innovative Technologies in Social Science. 7(28). doi: 10.31435/rsglobal_ijitss/30122020/7234

Copyright: (C) 2020 Shcherbak I. V. This is an open-access article distributed under the terms of the Creative Commons Attribution License (CC BY). The use, distribution or reproduction in other forums is permitted, provided the original author(s) or licensor are credited and that the original publication in this journal is cited, in accordance with accepted academic practice. No use, distribution or reproduction is permitted which does not comply with these terms.

Вступ. Стратегічні завдання розбудови системи вищої освіти України зумовлюють необхідність розв'язання наукових i практичних проблем, пов'язаних 3 професійною підготовкою майбутніх учителів. У сучасній українській системі вищої освіти помітно зростають вимоги до якості підготовки вчителя музичного мистецтва. Проблема формування й удосконалення професійної, зокрема інструментально-виконавської майстерності майбутніх учителів музичного мистецтва завжди знаходиться в центрі уваги науково-педагогічної думки.

Основні принципи педагогічної діяльності, спрямованої на формування виконавських дій у процесі навчання грі на музичному інструменті розглядалися в роботах Ю. Акімова, JI. Баренбойма, М. Баринової, Г. Когана, В. Лабунець, С. Мальцева, Я. Мільптейна, Г. Нейгауза, С. Савшинського, А. Сударикова та інших.

Дослідженнями в галузі створення художнього образу музичного твору, його культурнодуховного та індивідуально-особистісного змісту займались Б. Афанасьєв, В. Бесфамільнов, М. Бонфельд, О. Гараз, А. Гольденвейзер, Л. Гранецька, М. Давидов, С. Карась, Г. Нейгауз, I. Пуриц, Т. Рейзенкінд, О. Рудницька, О. Рябов, А. Сохор, В. Топілін, С. Фейнберг та інші.

Основи методики художньо-естетичного аналізу музики та формування уявлень про художній образ розкриті в дослідженнях таких вчених як Е. Абдуллін, О. Апраксина, 
Б. Асаф`єв, Ј. Баренбойм, Б. Барток, Н. Ветлугіна, Е. Жак-Далькроз, Д. Кабалевський, О. Лехнер, Л. Мазель, С. Назайкінський, В. Петрушин, О. Ростовський, М. Тіц, Ю. Холопов, Д. Христов, Г. Ципін, Б. Яворський та інші.

Незважаючи на це, ще не вирішеними залишаються питання подолання реально існуючих протиріч між рівнем підготовки майбутніх учителів музичного мистецтва до інструментального виконавства та сучасними вимогами до виконання його професійних обов'язків, реалізації музично-педагогічних, художньо-творчих завдань у роботі з учнями загальноосвітніх шкіл. Це потребує пошуків та розробки нових підходів до проблеми удосконалення інструментально-виконавської підготовки спеціалістів в галузі педагогіки музичного мистецтва.

На нашу думку, всі знання уміння та навички, необхідні учителю для здійснення своєї професійної діяльності, повинні формуватися у взаємодії, з урахуванням особливостей їх подальшого застосування у практичній діяльності. Опора на системний характер зв'язків, що поєднують складну структуру підготовки до інструментального виконавства, складовими якої виступають інтелектуально-когнітивний, художньо-емоційний, творчо-інтерпретаційний та операційно-виконавський компоненти, дає можливість досліджувати іiі цілісно, всебічно та як системне явище.

Мета статті - розгляд підготовки майбутніх учителів музичного мистецтва до інструментального виконавства крізь призму системного підходу та у взаємозв'язку із завданнями практичної виконавської діяльності спеціалістів у закладах загальної середньої освіти.

Методи дослідження: вивчення й аналіз нормативних документів, психологопедагогічної літератури 3 проблеми дослідження; інтегрування та конкретизація для характеристики особливостей підготовки майбутніх учителів музичного мистецтва до інструментального виконавства.

Результати дослідження. Багатоаспектність роботи вчителя музичного мистецтва в закладі загальної середньої освіти пояснюється сучасними вимогами до організації та проведення різних видів музичної та мистецької діяльності з учнями на уроках музичного мистецтва, що потребує від учителя не тільки систематичних і глибоких професійних знань, умінь та навичок, а й сформованості здатності до саморозвитку, самовдосконалення $[1,2,3,5]$. Реалізація усіх видів музично-виконавської діяльності учителя (сольне виконавство, самостійна робота над музичними творами, читання з листа, акомпанування, гра в ансамблі, творче музикування та імпровізація) повинні базуватись на синтезі виконавських та педагогічних якостей, розвинутому естетичному смаку та свідомому ставленню до музичного мистецтва.

Завдання озброєння студентів системою теоретичних знань в галузі музичного виконавства повинно реалізовуватись через розвиток їх інтелектуальних здібностей, формування жанрово-стильових орієнтирів, вмінь осмислювати та розуміти музичні форми $\mathrm{i}$ засоби виразності мистецтва.

Музикант повинен володіти системою теоретичних знань про стиль композитора, будову та структуру музичного твору, особливості гармонії та фактури. Науковці стверджують, що чим глибшими будуть знання про твір, тим більше вони збагатять уяву і мислення музиканта, поглиблять його розуміння мистецького твору, сприятимуть створенню художньопереконливої та яскравої інтерпретації музики [4,7].

Важливою є думка про те, що визначення ознак музичних стилів, жанрів, формоструктур, елементів художньої виразності відбувається у свідомості музиканта саме через систему уявлень та понять. Звідси випливає, що формування відповідних уявлень та понять має проходити одночасно та на основі практичної діяльності суб' єктів навчання, а саме музичного виконавства. Відомою $є$ наукова теза про те, що нова інформація може бути сприйнята та засвоєна людиною, якщо вона органічно входить у склад ії особистісного досвіду [11, с. 140]. Інструментальне виконавство на музичному інструменті, як художньо-практична діяльність, та постійне набуття музикантом виконавського досвіду складають потрібну основу для розвитку психічних та мисленнєвих операцій, необхідних для адекватного сприйняття, пізнання та творчої інтерпретації музичного мистецтва.

Практика інструментального виконавства в навчанні майбутніх учителів музичного мистецтва доводить, що здатність осмислювати музичні стилі і форми в достатній мірі розвинута не у всіх студентів. Як зазначав Й. Гете, матеріал бачить кожен, зміст знаходить 
лише той, хто має з ним щось спільне, форма ж залишається таємницею для більшості людей. Вивчення структури та форми музичного твору дозволяє зрозуміти, що його зміст виступає як цілісна єдність, всі елементи якої знаходяться у тісному гармонійному взаємозв'язку та розвитку. «Відчуття форми» (М. Гнесін), «архітектонічне почуття» (С. Савшинський) або «воля до форми» (К. Мартінсен) - це вміння осягнути композицію твору та визначити зміст і роль кожного її елемента [10, с. 141-142].

3 точки зору музично-інструментального навчання майбутніх вчителів музичного мистецтва цю проблему можна визначити як формування здатності здійснювати художньослухове та виконавське осягнення форми твору і створення на цій основі власної виконавської концепції, виконавського образу. Одною з головних умов ефективного освітнього процесу виступає внутрішній зворотній зв'язок, який забезпечує оптимальне керівництво пізнавальною діяльністю студентів. Він дає можливість оцінювати результати власної інструментальновиконавської діяльності самостійно, розвиваючи самоаналіз, самокритику, оцінні та рефлексивні вміння, активізуючи пізнавально-творчу сферу.

Діяльність музиканта, як і будь-яка мисленнєва діяльність, пов'язана з аналізом та синтезом. Це виявляється при вивченні музичного твору, осмисленні його мелодичної та гармонічної структури, пошуках виразових засобів втілення задуму композитора i, нарешті, у синтезі, узагальненні вищеназваного у своєму виконанні. Г. Ципін підкреслював, що «зв'язок між знаннями i відповідними формами художньо-інтелектуальної діяльності значно складніший, ніж той, що виражається причинно-наслідковою формою. Музичні і художні знання не просто дають поштовх тим чи іншим мисленнєвих операціям - вони формують ці операції, визначаючи їх структуру та внутрішній зміст. Нові знання піднімають мислення музиканта на більш високий рівень»,- зазначав автор [11, с. 134].

Формування готовності майбутніх учителів музичного мистецтва до інструментального виконавства відповідно до завдань практичної виконавської діяльності спеціалістів у закладах загальної середньої освіти передбачає володіння фундаментальними музично-теоретичними та методичними знаннями в галузі інструментально-виконавської діяльності, здатність виконувати музичні твори різних стилів, жанрів та форм, сформованість навичок і умінь самостійної роботи над музичним репертуаром; уміння розкривати художній образ музичного твору на основі емоційного сприйняття, опрацювання та інтерпретації музичних творів, розвиненість музичного сприйняття, уяви, мислення та творчих здібностей.

Засвоєння та накопичення нових знань, 3 одного боку, сприяє розвитку психічнорозумових процесів, з іншого $є$ можливим лише за умови відповідного рівня розвитку мислення людини. Подолання постійно виникаючих протиріч між новими знаннями та рівнем інтелектуального розвитку індивіда $є$ головною рушійною силою розвитку процесів мислення (сприйняття, уяви, фантазії тощо). Процес навчання $\epsilon$ ефективним, якщо засвоєння систематизованих знань $є$ стрижнем всього освітнього процесу. Адже дидактичний принцип систематичності передбачає засвоєння інформативних блоків знань та способів мисленнєвих дій у визначеному порядку, що забезпечує логіку освітнього процесу та максимальний розвиток пізнавальних можливостей особистості [10, с. 112]. Звертаючись до музики різних епох, осмислюючи ії естетико-стильові закономірності, типологічні форми, технологічні норми втілення художньо-образного задуму, майбутні вчителі музичного мистецтва постійно зустрічаються із закарбованими в них культурними реаліями сприйняття, психологією мистецького спілкування.

Інтелектуальний рівень пізнання майбутніми вчителями музичного мистецтва характеризуються усвідомленням законів та закономірностей музичної творчості, осмисленням важливих засобів музичної виразності для втілення художньо-образного змісту твору, наявність достатнього обсягу музично-теоретичних знань, широкої художньої ерудиції тощо [8, 9]. Механізми сприйняття музики та мислення художніми образами включають в себе аналіз і синтез, порівняння та узагальнення.

Отже, інтелектуальний розвиток музикантів не може бути досягнутий лише шляхом збільшення кількості їхніх знань. Вирішальне значення має оволодіння прийомами розумової діяльності, які б допомагали усвідомлювати та оцінювати смисл і характер музичної інформації, розуміти іï зміст, розмірковувати та робити висновки.

Найбільш суттєві недоліки практики навчання гри на музичному інструменті науковці часто пов’язують з недостатнім розвитком художньої свідомості музиканта. Такі фактори, як: 
незначний обсяг музичного та навчального матеріалу, обмеженість загальної та спеціальної художньої інформації, що сприймається, аналізується та осмислюється респондентами в процесі музичної діяльності, недостатній рівень їх активності та самостійності, а також вузькоспеціалізований підхід до формування виконавських умінь та навичок, - значною мірою гальмують процеси художнього розвитку музиканта. Педагогіка мистецтва підкреслює важливість організації навчання майбутніх учителів музичного мистецтва в умовах атмосфери емоційного напруження і зацікавленості у сприйнятті та осмисленні музики, тому значна увага відводиться формуванню активного художнього сприйняття музики, вмінь слухати іï, розуміти та оцінювати. «Звернення до емоційної складової музичної свідомості людини загальноприйнятий, так би мовити, магістральний шлях навчання гри на будь-якому музичному інструменті» [11, с. 138]. Сприйняття художньо-образного змісту музичного твору формує основи системи ключових мистецьких знань і в кінцевому результаті розвиває мислення.

Специфіка художньо-образного осягнення музики полягає в тому, що іiі зміст прихований у нотному тексті, а виконавське завдання міститься у його «розкодуванні», «розшифруванні». Цей процес здійснюється виконавцем шляхом перцептивного чуттєвого сприйняття, емоційного переживання, раціонального осмислення та створення на основі цього власної виконавської інтерпретації.

Всі етапи вивчення музичного твору являють собою послідовність систематично вирішуваних виконавцем професійних та творчих завдань. В такій площині проблема визначення логіки і структури роботи над музичним твором входить у прямий зв'язок 3 комплексом питань, об'єднаних темою виникнення, становлення та розвитку художнього образу в процесі художньої інтерпретації музики.

Проникнення у виразово-слуховий підтекст інтонації та осмислення логічної організації звукових структур націлює музикантів на створення цілісного художньо-музичного образу. «Розвиток музично-слухових уявлень йде від елементарних до більш змістовних та поглиблених, від фрагментарних та розрізнених до більш масштабних та узагальнених. В структуру даного явища, таким чином, включаються елементи формоутворюючого, жанрового, стильового порядку, що дає змогу просуватись від осмислення даного конкретного явища - до загальних уявлень про стиль, естетику історичної епохи та інше», - вказує Г. Ципін [11, с. 138].

Разом з тим процес формування слухових уявлень під час опанування мистецтва гри на музичному інструменті повинен доповнюватись розвитком вмінь роботи з авторським текстом, знаходження виконавських прийомів та засобів художньої виразності, формуванням навичок ескізного та детального опрацювання музичного матеріалу, його адекватного сприйняття тощо.

На першому етапі в процесі ознайомлення з нотним текстом музичного твору в уяві музиканта-виконавця формується емоційний художньо-звуковий образ. Первісне емоційне відображення набуває «виду загального симультанного уявлення, що містить в собі логіку розвитку змісту музичного твору» [10, с. 193]. На основі цього поступово починає виникати виконавська гіпотеза: від загальних відчуттів образного змісту твору здійснюється перехід до формування художнього образу, який в процесі аналізу та інтерпретації кристалізується, деталізується та збагачується шляхом пошуків відповідних засобів виразності [13].

При вивченні нового музичного твору активізується слухова та емоційна сфера виконавця. Чим більш яскравим, художньо неповторним є твір, тим енергійніше починається процес його творчого опрацювання музикантом на основі виникнення художніх асоціацій, музично-слухових уявлень. На цьому етапі метою педагогічної діяльності $є$ створення установки на формування початкового, недиференційованого образу твору та актуалізації особистісного досвіду музиканта, активізації його художньої свідомості.

Накопичення звукової інформації в процесі вивчення музичного твору сприяє розвитку аналітичних умінь, розробці виконавської концепції та апробування варіантів виконання твору.

Дії музиканта під час наступного етапу роботи спрямовані на вирішення руховотехнічних завдань, вдосконалення деяких елементів фактури, створення остаточного варіанту художньо-виконавської концепції. Насправді робота над покращенням звукової форми твору по суті є уточненням, шліфовкою художнього образу у свідомості музиканта-виконавця [10, с. 146].

Отже, кожен виконавець спочатку створює в уяві художньо-музичний образ твору, а вже потім втілює його на інструменті. Тільки в цьому випадку його гра стає творчим актом, що перетворює світ графічних символів та слухових уявлень у реальне звучання. Формування 
здатності внутрішнім слухом заздалегідь уявляти звуковий образ музики є дуже важливим для створення відповідного виконавського стану музиканта, розвитку його виконавської інтуїції тощо.

Саме уява стає тим підгрунтям, на якому базуються вміння майбутніх учителів музичного мистецтва не тільки яскраво виконувати музичний твір, а й майстерно орієнтуватись у його художньо-образному змісті, презентувати його за допомогою словесно-поетичних характеристик, вербально-емоційної складової. Ці вміння необхідні фахівцю для більш чіткого усвідомлення власної виконавської концепції, а також більш переконливої характеристики творів, що звучать на уроках музичного мистецтва в закладах загальної середньої освіти.

Потрібно, щоб уява виконавця була спрямована не тільки на музичне звучання, а й створення образу ігрового руху. Важливо не тільки контролювати звук, а й займатись підбором та організацією прийомів звуковидобування. Під час гри потрібно не піклуватися про власні емоції та психічні стани, а передавати художньо-образний зміст музики, інтегративно вирішуючи музично-педагогічні та виконавсько-технічні завдання. Професійна діяльність майбутніх учителів-виконавців обумовлюється взаємодією звукових, тактильних та рухових відчуттів, але головна роль належить слуховим, а саме: звуковисотним, мелодичним, гармонічним, поліфонічним, тембральним, фактурним відчуттям тощо.

В. Петрушин зазначає: «Мистецтво гри на музичному інструменті базується на принципі єдності художнього образу та технічної майстерності, яка дозволяє музиканту донести все, що він бажає виразити та висловити своїм виконанням. Постійне удосконалення технічної майстерності - це, по суті, робота музиканта над розширенням своїх можливостей у втіленні художніх образів» [6, с. 148].

Музичне переживання має не тільки слухову, а й рухову природу, тобто завжди пов'язане 3 різноманітними рухами, як при виконанні музики, так i при iї сприйняті. Мимовільні похитування тілом, відбивання ритму рукою чи ногою, підспівування - усе це прояви моторної природи музичного переживання [6, с. 144]. Здатність до здійснення чітких, художньо-обумовлених, вправних ігрових рухів $є$ таким же важливим досягненням музиканта, як і розвинений слух, гарна музична пам'ять тощо. Тому дуже важлива роль практичних дій та операцій у навчанні, де постійно необхідно звертати увагу на психологічні закономірності поєднання процесів мислення, творчості, емоцій та роботи рук, моторики музиканта-виконавця.

Як правило, виконавець завжди прагне не стільки детально передати текст твору, як «відновити» його, пропускаючи через себе думки і переживання автора. Разом з тим, музикант повинен показати своє ставлення до музики, розповісти слухачам про свої переживання i відчуття. В залежності від виконавської манери музиканта, його художньої індивідуальності, зміст твору розкривається по-різному. Тому музична педагогіка завжди наголошує на важливості збереження та розвитку індивідуальної виконавської неповторності у професійній діяльності вчителя музичного мистецтва. В iï основі лежать: художній світогляд особистості, ступінь розвитку інтелекту, культури, художнього смаку виконавця, наявність вольових та професійних якостей учителя, а також високий рівень володіння виконавською технікою, артистичність.

В процесі роботи над музично-педагогічним репертуаром увагу студентів потрібно звертати на формування вмінь та навичок відбору найбільш цікавого, художньо досконалого музичного матеріалу, досягнення високого професійного рівня його виконання [12]. Майбутнім учителям музичного мистецтва також необхідно володіти методикою самостійної роботи над музичним твором (виконання окремих голосів, фраз, періодів; опрацювання особливостей ритмічної, артикуляційної, динамічної, жанрово-стилістичної організації музичного матеріалу; подолання виконавських та технічних складнощів тощо).

У повсякденній роботі майбутнім учителям музичного мистецтва потрібні навички підбору знайомих мелодій на слух 3 додаванням до них акомпанементу, гармонізації та інструментального перекладу музичних уривків, володіння прийомами творчого музикування та імпровізації. Формування цих умінь потребує достатнього періоду часу та найбільш ефективно здійснюється в процесі постійної, кропіткої та цілеспрямованої роботи студентів у класі інструментально-виконавської підготовки.

Висновки. Підвищення якості професійної підготовки майбутніх учителів музичного мистецтва, зокрема удосконалення їх інструментально-виконавської майстерності $\epsilon$ одним із провідних завдань сучасної музично-педагогічної освіти. Виявлення системних зв'язків у структурі підготовки майбутніх учителів музичного мистецтва до інструментального 
виконавства, організація освітнього процесу 3 урахуванням закономірностей розвитку їх художньої свідомості, застосування сучасних педагогічних технологій та інноваційних методів роботи у комплексі можуть забезпечити суттєве підвищення рівня підготовки спеціалістів та ефективність їх професійної діяльності у закладах загальної середньої освіти. Це, на нашу думку, є основним напрямком подальших наукових розвідок у даному напрямку.

\section{REFERENCES}

1. Ministry of Education and Science of Ukraine. (2020). Zakon Ukrayiny «Pro vy shhu osvitu» [Law of Ukraine "On Higher Education"] (Law № 1556-VII, March 18). Retrieved from: https://zakon.rada.gov.ua/laws/show/1556-18

2. Ministry of Education and Science of Ukraine. (2020). Zakon Ukrayiny "Pro povnu zagal nu serednyu osvitu» [Law of Ukraine "On Complete General Secondary Education"] (Law № 463-IX, January 16). Retrieved from: https://zakon.rada.gov.ua/laws/show/463-20

3. Ministry of Education and Science of Ukraine. (2020). Zakon Ukrayiny «Pro osvitu» [Law of Ukraine "On Education"] (Law № 2145-VIII, April 2). Retrieved from: https://zakon.rada.gov.ua/laws/show/2145-19

4. Labunecz’, V. M. (2014). Innovacijni texnologiyi instrumental’no-vy`konavs `koyi pidgotovky`majbutn`ogo vchy`telya muzy`chnogo my`stecztva: teoriya ta metody`ka [Innovative technologies of instrumental and performance training of future music teachers: theory and methods]. Redakcijno-vy`davny`chy`j viddil Kam'yanecz'-Podil's`kogo derzhavnogo universy`tetu imeni Ivana Ogiyenka.

5. Gry`nevy`ch, L., El`kin, O., Kalashnikova, S., Koberny`k, I., Kovtunecz`, V., Makarenko, O., ...Shy`yan, R. (2016). Nova ukrayins`ka shkola. Konceptual’ni zasady` reformuvannya seredn`oyi shkoly` [New Ukrainian school. Conceptual principles of secondary school reform]. Kyiv. Retrieved from: https://mon.gov.ua/storage/app/media/zagalna\%20serednya/nova-ukrainska-shkola-compressed.pdf

6. Petrushin, V. I. (1997). Muzykal'naja psihologija [Music psychology]. Moskva: Vlados.

7. Rejzenkind, T.J. (2008). Teorety`ko-metody`chni zasady`profesijnoyi pidgotovky` majbutn`ogo vchy`telya muzy`ky` $u$ vy`shhyx navchal'ny`x zakladax [Theoretical and methodological principles of professional training of future music teachers in higher educational institutions] (Dissertation Abstract, Kyiv).

8. Rostovs'kyy, O. Ya. (2001). Metodyka vykladannya muzyky v osnovniy shkoli [Methods of teaching music in basic school] ( $2^{\text {nd }}$ ed.). Ternopil': Navchal'na knyha Bohdan.

9. Rudny`cz`ka, O. P. Pedagogika. Zagal`na ta my`stecz `ka [Pedagogy. General and artistic]. Ternopil`: Bogdan.

10. Kauzovoj, A.G., Nikolaevoj, A.I. (Eds.). (2001). Teorija i metodika obuchenija igre na fortepiano [Theory and methodology of learning to play the piano]. Moskva: Vlados.

11. Cypin, G. M. Obuchenie igre na fortepiano [Learning to play the piano]. Moskva: Prosveshhenie.

12. Shcherbak, I. V. (2019). Rozvy`tok profesijny`x vlasty`vostej majbutn`ogo vchy`telya muzy`chnogo my`stecztva [Development of professional properties of future teachers of musical art]. Naukovi zapy`sky, 174. Seriya: Pedagogichni nauky` - Kropy`vny`cz'ky`j: RVV CzDPU im. V. Vy`nny`chenka [Scientific notes, 174. Series: Pedagogical sciences. - Kropivnytsky: RVV CDPU them. V. Vynnychenko], 159-164. Retrieved from: https://www.cuspu.edu.ua/images/download-files/naukovi-zapysky/176/nz_176-159-163.pdf 